\title{
Assessing Patients' Satisfaction with the Quality of Ophthalmic Services at Saint John Gaza Eye Clinic
}

\author{
Murad Alkhalaileh, ${ }^{1, *}$, Abd Al-Hadi Hasan², Naeem S Al-Kariri ${ }^{3}$, Ali H Abu Ibaid ${ }^{4}$ \\ ${ }^{1}$ Adult Health Nursing, Fakeeh College for Medical Sciences, Nursing Department, Jeddah, Kingdom of Saudi Arabia \\ ${ }^{2}$ Mental Health Nursing, Fakeeh College for Medical Sciences, Nursing Department, Jeddah, Kingdom of Saudi Arabia \\ ${ }^{3}$ Clinical Nursing Supervisor, Ranteesy Specialized Paediatric Hospital-Gaza-Palestine, Master of Public Health \\ ${ }^{4}$ Health System Officer, World Health Organization-oPt \\ *Corresponding author: malkhalaileh@fakeeh.care
}

\begin{abstract}
Objective: This study aimed to assess the patients' satisfaction with health services provided at Outpatients' ophthalmology clinic Department at Saint John Hospital. Methods: The design of this study is descriptive, analytical. 309 participants were recruited from the Outpatients' eye Department at Saint John Hospital. Results: Five dimensions of patients' satisfaction were considered in this study; namely, access to care, physical environment, patients' expectations, waiting time in addition to information and interaction. The overall patients' level of satisfaction was $63.9 \%$. The patients' expectation dimension reported the highest level of satisfaction (68.1\%), while, the waiting time dimension reported the lowest level of satisfaction (58.5\%). The study illustrated important differences in satisfaction in relation to patients' socio-demographic characteristics, health status and organizational characteristics. Discussion: The study revealed that, there were statistically significant differences in the overall satisfaction with old patients, females, low educated, patients with low income and patients with chronic diseases are more satisfied than their counterparts. Conclusion: The study recommended that reducing the patients' time in the outpatient clinic, introducing improvement on existing physical environment of the department and improving the way of communication and interaction between health care providers and patients are important factors for improving the patients' level of satisfaction.
\end{abstract}

Keywords: patients' Satisfaction, quality of Services, outpatient

Cite This Article: Murad Alkhalaileh, Abd Al-Hadi Hasan, Naeem S Al-Kariri, and Ali H Abu Ibaid, "Assessing Patients' Satisfaction with the Quality of Ophthalmic Services at Saint John Gaza Eye Clinic." American Journal of Public Health Research, vol. 5, no. 1 (2017): 15-22. doi: 10.12691/ajphr-5-1-4.

\section{Introduction}

Over the past few decades, patients' views of points regarding the assessment of services have gained much spread in the medical research [1]. At the same time, each health care facility nowadays is concerned with satisfying the users of its products or services who are known as clients, customers, consumers or patients. Satisfaction, like many other psychological concepts, is easy to understand but hard to define. Concept of satisfaction is not some pre-existing phenomenon waiting to be measured, but is a judgment of people constituted with time as a reflection of their experience [2]. Patient satisfaction depends on personal care given by the provider, presence of medical staff on a continuous basis, treatment outcomes, the way of delivering health care, the type of health care setting, and patient characteristics as age, gender education, socio economic status [3]. To the best of our knowledge, little research has been conducted on patient satisfaction with eye care services in Gaza strip.

A study was conducted in India to explain patients' opinions regarding the determinants of eye care services in eye care clinics using a random sample of 127 patients by interviewing those patients to determine and predict their satisfaction with the quality of eye care services [4]. The authors used factor analysis to determine the pillars of patients' satisfaction which included availability of vision technician and workers, place of that technician and accessibility of patients to vision technician which interprets $60 \%$ of the total level of patients" satisfaction with vision technician. Another important finding of this study revealed that patients with limited accessibility to location of vision technician and patients who had the affordability to pay for service fees had less satisfaction with the delivered eye care service. The authors concluded that skilled vision technicians could improve patients' satisfaction with eye care services. Moreover, patients' expectation, affordability of eye care, and suitable transportation are all important factors which could promote patients' satisfaction with the delivered eye care services. The previous components are essential in enhancing patients experience and satisfaction with eye care services in health care facilities [4].

A descriptive study was conducted by Yousef and Naeem [5] (2010) to evaluate patients' satisfaction with the health services delivered at the outpatient department of Alshifa hospital using probability systematic random sample of 450 participants. A self-administered survey 
was used to collect data from participants which consist of 75 items divided into 2 subscales, socio-demographic data which comprise 18 items and 57 items which covers 5 aspects of patients' satisfaction. The self-administered survey used in that study is a valid and reliable with 0.91 Cronbachs' alpha. Findings of that study revealed that the overall level of patients' satisfaction was $63.9 \%$ with the highest level in patients' expectations and the lowest level in the waiting time. Another important finding of this study indicated that old patients, females, patients with low educational level, low income and chronic diseases are more satisfied with quality of health services than other patients. These findings could be attributed to the sensitive nature of satisfaction with the quality of health services among patients because the concept of satisfaction is a subjective matter and is concerned with psychological status of patients [5].

In Iran, a study was conducted to evaluate patients' satisfaction with health care services in eye care hospital using systematic random sample of 539 patients [6]. The authors used the Patient Satisfaction Questionnaire to collect the study data which covers 8 relevant aspects of patients' satisfaction. Findings of this study revealed a great association between accessibility to eye health care services, the technical aspect of quality of health care with the overall satisfaction. Another important finding using the regression model indicated a prediction of $60 \%$ with the overall satisfaction level. This study presents accessibility to health care services and technical quality of such services as the key driver for improving patients' satisfaction with the quality of health care services [6].

A cross sectional study was conducted by Ibrahim, Chompikul [7] to evaluate patients' satisfaction with the quality of health services at outpatients department in Indian hospital. Sample size of this study consisted of 251 patients using a structured survey to collect the study data. Findings of this study showed that $10.4 \%$ of patients showed high satisfaction level with health care services, $45.8 \%$ of patients showed high level of satisfaction with courtesy, $44.2 \%$ of them showed high satisfaction with quality of care, $41.8 \%$ of patient had high satisfaction with physical environment, $24.7 \%$ with convenience, and 23.5\% with out of pocket cost. Another important finding of this study showed that most patients had a great concern regarding waiting time to see their physician which could be improved by increasing availability of more physicians at the hospital which have a strong impact on patients' satisfaction with the quality of health services [7].

A descriptive study was conducted in India to assess patients' satisfaction with the quality of eye care services using a random sample of 320 patients who were interviewed individually using a standardized/ structured questionnaire form which covers multiple aspects of patients' satisfaction to assess patients' perspectives regarding their satisfaction with the delivered eye care services [8]. The most important findings of Sudhan, Khandekar [8] study revealed that 48.1 of participants who received treatments at outpatients clinic had high satisfaction level while $97.5 \%$ of patients who got treatments in the hospital had high satisfaction level. At the same line, majority of participants had low satisfaction level with the waiting time in the clinic, and the poor status of cleanliness.

In Gaza strip, a descriptive, cross sectional study was conducted by Mourad, Shashaa [9] to evaluate patients' satisfaction with community mental health services delivered to patients in 6 governmental community mental health clinics using a structured questionnaire to collect the study data from 400 patients who have been selected randomly. The questions used in the instrument covered 6 aspects of patients' satisfaction including general impressions, access to eye care services, communication, interaction and information, physical environment of the facility, technical quality and convenience and responsiveness to patients.

The most important findings of Mourad, Shashaa [9] study showed that patients' satisfaction with the quality of eye care services ranged from $58.1 \%$ to $77.8 \%$. Also, the highest patients' satisfaction was related to the physical environment; however, the lowest satisfaction level was in access to the eye care services. At the same line, the study results found a statistical significant difference between patients' living place and their satisfaction with eye care services while there was no statistical significant difference between patients' age, sex marital status, education, income and their satisfaction with eye care services.

In Germany, a study was conducted by Schoenfelder, Klewer [10] to determine factors linked with satisfaction of patients who got eye care health services through selfadministered survey of 507 patients who were selected randomly from 7 eye clinic. The authors used an instrument which covers multiple aspects of patients' satisfaction with eye health care. The most important findings of this study produced 2 significant factors using factor analysis. Moreover, there were high correlation between total satisfaction level and perceived level of health care while there were low correlation between total satisfaction level and visit to eye clinic. It was inferred that the most important factors of patients" satisfaction with eye care services include the arrangements of procedures and operations in addition to other moral factors such as the courtesy of the medical team in addition to the subjective experiences of satisfaction among patients [10]. A descriptive cross sectional study was conducted by Rizyal (2012) to evaluate patients' satisfaction with the quality of health care services provided at ophthalmology department in a university hospital in Nepal. The author covered 5 important dimensions of patients' satisfaction which include accessibility to health care services, waiting time, clienthealth care provider relationship, service affordability, and hospitals' environment. The most important findings of this study revealed that $75.5 \%$ of patients were satisfied with accessibility to health care services while clientphysician relationship scored $87.9 \%$, service affordability had $76.8 \%$, and $62 \%$ for waiting time dimension. It is greatly important to assess patients' satisfactions regularly to promote quality of health care services which should be integrated in the corporate strategy of health care organizations (Rizyal, 2012).

Globally, more than 161 million people were visually impaired, of whom 124 million people had low vision and 37 million were blind. However, refractive error as a 
cause of visual impairment was not included, which implies that the actual global magnitude of visual impairment is of greater concern. Worldwide for each blind person, an average of 3.4 people has low vision, with country and regional variation ranging from 2.4 to 5.5 (WHO, 2014). Data over the last 20 years shows that there has been significant progress in preventing and curing visual impairment in many countries. This has been achieved through a number of successful international partnerships (WHO, 2014).

The current study assessed the patients' level of satisfaction with the quality of ophthalmic services provided at St. John eye clinic. These dimensions included access to care, physical environment, patients' expectations, waiting time in addition to information and interaction. The researchers evaluated patients' level of satisfaction with these services from patient's perspective.

Patient's satisfaction studies show different and new dimensions of health care, which provide an open view towards improving the quality of patient's life, and increase health professionals and public awareness regarding health. One of the major problems in Palestinian health care system is the lack of considering clients' satisfaction [5]. Client satisfaction evaluations are an excellent opportunity to involve clients or patients in the process of improving work activities (WHO, 2000). Many patients' satisfaction studies were conducted to evaluate provided health services in various fields of health in Gaza Strip, Studies on patients' satisfaction with ophthalmic services have been carried out in the developed world, but very few studies have been reported in Gaza Strip. Therefore, the present study is unique in that it attempted to assess patients' satisfaction with the quality of eye care services at St. John eye clinic and to examine the impact of different dimensions on overall satisfaction. Saint John Gaza eye clinic considered the second main eye care provider in Gaza strip. During 2013, a number of 25769 consultations were provided to the people of Gaza. Also, 1207 major surgeries were conducted in the same year.The aim of this study was to assess patients' level of satisfaction with the quality of ophthalmic services provided at St. John eye clinic in Gaza Strip.

\section{Methods}

\subsection{Study Design}

The design of this study is descriptive, analytical one. This design is useful for descriptive studies, inexpensive, can provide analytic clues, less prone to error about exposure recall, and enables the researcher to collect needed data over a short period of time, it's useful in satisfaction studies and sometimes used for comparison purposes [11].

\subsection{Participation}

The target population was all patients who received ophthalmic care in hospitals and clinics of Gaza strip. Accessible population was all patients who arrived and received ophthalmic care at Saint John eye clinic in Gaza at the time of the study. Inclusion criteria include all patients who arrived at Saint John eye clinic for treatments at the time of data collection (March, and May, 2014), able and accept participation, conscious and oriented to time, place and persons. Exclusion criteria included all patients who arrived to Saint John eye clinic at the time of the study and weren't meet the above criteria have been excluded from the study.

\subsection{Sampling Procedure}

Saint John eye clinic is a branch of Saint John eye hospital in Jerusalem. The clinic serves people of Gaza strip since 1992. It has a high turnover of outpatient clients, with nearly 1471 ophthalmic surgeries, 25769 outpatient visits in the year 2013. In this study, convenience sample was used to recruit the participants in Saint John eye clinic.

\subsection{Sample Size}

Statistical power analysis was used to determine the sample. To have an adequate sample size for this study, the alpha level is set at 0.05 , the effect size is medium and the power is set at 0.80 . The estimated sample size is 85 subjects [12]. With a power of 0.95 and a medium effect size, the estimated sample was 140 subjects. The final Sample size was 309 participants who completed the survey.

\subsection{Data Collection Procedure}

After the approval being obtained, the investigator approached the participants in the study setting. All participants were invited to take part after explaining the purpose of the study. Principle investigator (PI) met the director of Saint John eye clinic and explained the overall aim of the study before distributing the questionnaires among participants. Then, the patients were interviewed inside the study setting after receiving their care, and were asked to fill the questionnaire with assistance of the researcher. Collection of data continued over six weeks (30 days).

\subsection{Instrument}

A self-administered questionnaire developed by Yousef and Naeem [5] to assess patients' satisfaction with the quality of health care services in outpatient departments at Alshifa hospital was used in this study. The instrument used in this study has 74 items (59 items with Likert- type questions and 15 items open ended questions). The first part consists of 15 items and includes information about patient's demographic, socio-economic, patients' health status and organizational characteristic such as gender, age, level of education, income, residency place, need for assistant during visit, type of the disease (for more details, see Appendix A).The second part consists of 5 subscales. The first subscale is access to care which consists of 8 items. The second subscale is the physical environment in the clinic, consists of 11 items. The third subscale is the patients' expectations, consists of 13 items. The fourth subscale is the waiting time, consists of 11 items. The fifth subscale is the information and interaction, consists of 17 
items. All response options in the aforementioned subscales range from 1 to 5 (Strongly Disagree to Strongly Agree).

Cronbach's alpha internal consistency reliability for complete items of The Classical Arabic version of The Patients' Satisfaction Questionnaire was 0.91, which is supported the value of internal consistency reliability of the original instrument, which was 0.91 [5]. Cronbach's alpha internal consistency reliability for the five subscales was 0.52 for access to care subscale, 0.88 for the physical environment subscale, 0.89 for patients' expectations' subscale, 0.87 for waiting time subscale, 0.93 for interaction and communication subscale.

\subsection{Data Analysis}

Data analysis was done by the researcher with consultations of the statistician. Means and Standard Deviations $(S D)$ have been computed for the continuous numeric variables. To illustrate the main characteristics of the respondents, frequency tables have been used. Advanced statistical analysis was conducted to explore potential relationships between variables, student t-test and one way ANOVA test to examine potential relationships between the continuous variables. $P$ value equal or less than 0.05 was considered statistically significant. All these tests have been performed to investigate the relationships between the independent study variables (access to care, physical environment, patients' expectations, waiting time in addition to information and interaction), with the selected patient's demographic, socio-economic, health status characteristics and organizational factors that may affect the patients' level of satisfaction.

\section{Results}

307 participants were provided consent form and returned questionnaire. Females represented $66.4 \%$ of the study sample and the majority of participants aged more than 25 years, residing within Gaza governorate. In addition, two thirds of the study sample were married. Less than half of them attained secondary or higher level of education. More than $80 \%$ of participants' income considered in the poorest area. In terms of organization characteristics, $60 \%$ of study participants were visited medical clinic on regular basis with average of time consuming per visit was less than an hour, particularly at doctor clinic.

Differences in patient's satisfaction and characteristics of the study population

Differences in patient's satisfaction by gender

An independent t-test compared the means of satisfaction scores revealed that there was no statistical significance in patients' satisfaction. However, patients elicited convergent scores in all domains and overall satisfaction. This result may be attributed to the good ophthalmic care provided at the Saint John eye clinic without discrimination between patients regarding their gender. The results are shown in Table 1.

\section{Differences in patient's satisfaction by age groups}

One Way ANOVA was used to determine the differences in patients' satisfaction with regard to age groups. The results showed that differences were not statistically significant in all domains and the overall satisfaction of the study. However, the t test showed that those patients who were received eyes' care in the Saint John clinic have the same degree of satisfaction. This result may reveal that all patients in any age group received eye care in the same manner, as indicated in the Table 2.

\section{Differences in patient's satisfaction by marital status}

The findings of one way ANOVA illustrated that the differences were statistically not significant except in access to care (P- value 0.021$)$. Also, the results revealed that the widow group has had highest scores of satisfactions. The researcher attributed this result to that the married patients seek to treatment more than unmarried and they facilitated the means to attend to the health center, as illustrated in the Table 3. Regarding the widow patients, who have had the highest mean scores of satisfactions, this may be attributed to pay attention by the widow patients regarding their health and facilitate means to access to the care they need. Married patients have had higher mean scores of overall satisfactions than unmarried patients, this means that patients who were married satisfied more than unmarried patients, and may indicated that married patients have a previous experience about the services provided at the hospital.

Table 1. Differences in patient's satisfaction by gender

\begin{tabular}{|c|c|c|c|c|c|}
\hline $\begin{array}{c}\text { Dep. var. } \\
\text { "Patient Satisfaction" }\end{array}$ & $\begin{array}{l}\text { Indep. var. } \\
\text { "Sex" }\end{array}$ & $\mathbf{N}$ & Mean & $\mathbf{T}$ & P-Value \\
\hline \multirow{2}{*}{ Access to care } & Male & 208 & 29.9856 & \multirow{2}{*}{-1.462} & \multirow{2}{*}{.145} \\
\hline & Female & 197 & 30.6294 & & \\
\hline \multirow{2}{*}{ physical environment } & Male & 208 & 33.2548 & \multirow{2}{*}{-1.802} & \multirow{2}{*}{.072} \\
\hline & Female & 197 & 34.1726 & & \\
\hline \multirow{2}{*}{ Patients' expectations } & Male & 208 & 42.7981 & \multirow{2}{*}{-4.133} & \multirow{2}{*}{$.001 *$} \\
\hline & Female & 197 & 45.8376 & & \\
\hline \multirow{2}{*}{ Waiting time } & Male & 208 & 37.4808 & \multirow{2}{*}{-1.822} & \multirow{2}{*}{.069} \\
\hline & Female & 197 & 38.6041 & & \\
\hline \multirow{2}{*}{ Information \& Interaction } & Male & 208 & 41.0529 & \multirow{2}{*}{-2.493} & \multirow{2}{*}{$.013 *$} \\
\hline & Female & 197 & 43.1269 & & \\
\hline \multirow{2}{*}{ Overall satisfaction } & Male & 208 & 184.5721 & \multirow{2}{*}{-3.295} & \multirow{2}{*}{$.001^{*}$} \\
\hline & Female & 197 & 192.3706 & & \\
\hline
\end{tabular}

* P- value statistically significant at level equal or less than 0.05 . 
Table 2. Differences in patient's satisfaction by age groups

\begin{tabular}{|c|c|c|c|c|c|c|c|}
\hline $\begin{array}{c}\text { Dep. var. } \\
\text { "Patient Satisfaction" }\end{array}$ & $\begin{array}{c}\text { Age } \\
\text { groups }\end{array}$ & No. & Mean & $\begin{array}{l}\text { Indep.var. } \\
\text { Age groups }\end{array}$ & DF & $\mathbf{F}$ & p-value \\
\hline \multirow{4}{*}{$\begin{array}{l}\text { Access to } \\
\text { Care }\end{array}$} & Less than 24 years & 106 & 30.2075 & \multirow{4}{*}{$\begin{array}{l}\text { Between } \\
\text { Groups }\end{array}$} & \multirow{4}{*}{$\begin{array}{c}3 \\
401\end{array}$} & \multirow{4}{*}{.476} & \multirow{4}{*}{.699} \\
\hline & From 25-34 years & 99 & 29.9293 & & & & \\
\hline & From 35-46 years & 99 & 30.4040 & & & & \\
\hline & More than 46 years & 101 & 30.6535 & & & & \\
\hline \multirow{4}{*}{ Physical environment } & Less than 24 years & 106 & 32.9623 & \multirow{4}{*}{$\begin{array}{l}\text { Between } \\
\text { Groups }\end{array}$} & \multirow[b]{2}{*}{3} & \multirow{4}{*}{3.498} & \multirow{4}{*}{$.016^{*}$} \\
\hline & From 25-34 years & 99 & 32.9293 & & & & \\
\hline & From 35-46 years & 99 & 34.0505 & & 401 & & \\
\hline & More than 46 years & 101 & 34.8911 & & & & \\
\hline \multirow{4}{*}{$\begin{array}{c}\text { Patients' } \\
\text { Expectations }\end{array}$} & Less than 24 years & 106 & 43.8113 & \multirow{4}{*}{$\begin{array}{l}\text { Between } \\
\text { Groups }\end{array}$} & \multirow{4}{*}{401} & \multirow{4}{*}{2.524} & \multirow{4}{*}{.057} \\
\hline & From $25-34$ years & 99 & 43.6768 & & & & \\
\hline & From $35-46$ years & 99 & 43.5657 & & & & \\
\hline & More than 46 years & 101 & 46.0495 & & & & \\
\hline \multirow{4}{*}{$\begin{array}{l}\text { Waiting } \\
\text { time }\end{array}$} & Less than 24 years & 106 & 37.5000 & \multirow{4}{*}{$\begin{array}{l}\text { Between } \\
\text { Groups }\end{array}$} & \multirow{4}{*}{$\begin{array}{c}3 \\
401\end{array}$} & \multirow{4}{*}{2.502} & \multirow{4}{*}{.059} \\
\hline & From $25-34$ years & 99 & 37.1515 & & & & \\
\hline & From $35-46$ years & 99 & 38.1010 & & & & \\
\hline & More than 46 years & 101 & 39.3663 & & & & \\
\hline \multirow{4}{*}{ Information \& Interaction } & Less than 24 years & 106 & 40.0377 & \multirow{4}{*}{$\begin{array}{l}\text { Between } \\
\text { Groups }\end{array}$} & \multirow{4}{*}{$\begin{array}{c}3 \\
401\end{array}$} & \multirow{4}{*}{5.907} & \multirow{4}{*}{$.001 *$} \\
\hline & From 25-34 years & 99 & 41.6869 & & & & \\
\hline & From $35-46$ years & 99 & 41.8081 & & & & \\
\hline & More than 46 years & 101 & 44.8020 & & & & \\
\hline \multirow{4}{*}{$\begin{array}{l}\text { Overall } \\
\text { satisfaction }\end{array}$} & Less than 24 years & 106 & 184.5189 & \multirow{4}{*}{$\begin{array}{l}\text { Between } \\
\text { Groups }\end{array}$} & \multirow{4}{*}{$\begin{array}{c}3 \\
401\end{array}$} & \multirow{4}{*}{4.721} & \multirow{4}{*}{$.003^{*}$} \\
\hline & From 25-34 years & 99 & 185.3737 & & & & \\
\hline & From $35-46$ years & 99 & 187.9293 & & & & \\
\hline & More than 46 years & 101 & 195.7624 & & & & \\
\hline
\end{tabular}

* P-value statistically significant at level equal or less than 0.05 .

Table 3. Differences in patients' satisfaction by marital status

\begin{tabular}{|c|c|c|c|c|c|c|c|}
\hline $\begin{array}{c}\text { Dep. var. } \\
\text { "Patient Satisfaction" }\end{array}$ & Marital status & No & Mean & $\begin{array}{c}\text { Indep. var. } \\
\text { Marital status }\end{array}$ & DF & $\mathbf{F}$ & p-value \\
\hline \multirow{4}{*}{ Access to care } & Married & 274 & 29.9015 & \multirow{4}{*}{$\begin{array}{l}\text { Between } \\
\text { Groups }\end{array}$} & \multirow{4}{*}{$\begin{array}{c}3 \\
401\end{array}$} & \multirow{4}{*}{3.277} & \multirow{4}{*}{$.021 *$} \\
\hline & Unmarried & 108 & 30.8333 & & & & \\
\hline & Divorced & 3 & 31.6667 & & & & \\
\hline & widow & 20 & 32.6500 & & & & \\
\hline \multirow{4}{*}{ Physical environment } & Married & 274 & 33.7336 & \multirow{4}{*}{$\begin{array}{l}\text { Between } \\
\text { Groups }\end{array}$} & \multirow{4}{*}{$\begin{array}{c}3 \\
401\end{array}$} & \multirow{4}{*}{.417} & \multirow{4}{*}{.741} \\
\hline & Unmarried & 108 & 33.4167 & & & & \\
\hline & Divorced & 3 & 33.6667 & & & & \\
\hline & widow & 20 & 34.8000 & & & & \\
\hline \multirow{4}{*}{ Patients' expectations } & Married & 274 & 43.9854 & \multirow{4}{*}{$\begin{array}{l}\text { Between } \\
\text { Groups }\end{array}$} & \multirow{4}{*}{$\begin{array}{c}3 \\
401\end{array}$} & \multirow{4}{*}{1.825} & \multirow{4}{*}{.142} \\
\hline & Unmarried & 108 & 44.2963 & & & & \\
\hline & Divorced & 3 & 45.0000 & & & & \\
\hline & widow & 20 & 48.0500 & & & & \\
\hline \multirow{4}{*}{ Waiting Time } & Married & 274 & 37.9380 & \multirow{4}{*}{$\begin{array}{l}\text { Between } \\
\text { Groups }\end{array}$} & \multirow{4}{*}{$\begin{array}{c}3 \\
401\end{array}$} & \multirow{4}{*}{1.309} & \multirow{4}{*}{.271} \\
\hline & Unmarried & 108 & 37.7407 & & & & \\
\hline & Divorced & 3 & 39.0000 & & & & \\
\hline & widow & 20 & 40.6500 & & & & \\
\hline \multirow{4}{*}{$\begin{array}{l}\text { Information \& } \\
\text { Interaction }\end{array}$} & Married & 274 & 42.1168 & \multirow{4}{*}{$\begin{array}{l}\text { Between } \\
\text { Groups }\end{array}$} & \multirow{4}{*}{$\begin{array}{c}3 \\
401\end{array}$} & \multirow{4}{*}{1.669} & \multirow{4}{*}{.173} \\
\hline & Unmarried & 108 & 41.2130 & & & & \\
\hline & Divorced & 3 & 43.0000 & & & & \\
\hline & widow & 20 & 45.7500 & & & & \\
\hline \multirow{4}{*}{$\begin{array}{c}\text { Overall } \\
\text { Satisfaction }\end{array}$} & Married & 274 & 187.6752 & \multirow{4}{*}{$\begin{array}{l}\text { Between } \\
\text { Groups }\end{array}$} & \multirow{4}{*}{$\begin{array}{c}3 \\
401\end{array}$} & \multirow{4}{*}{2.274} & \multirow{4}{*}{.079} \\
\hline & Unmarried & 108 & 187.5000 & & & & \\
\hline & Divorced & 3 & 192.3333 & & & & \\
\hline & widow & 20 & 201.9000 & & & & \\
\hline
\end{tabular}

* P-value statistically significant at level equal or less than 0.05 . 
Table 4. Differences in patient's satisfaction by level of education

\begin{tabular}{|c|c|c|c|c|c|c|c|}
\hline $\begin{array}{c}\text { Dep. var. } \\
\text { "Patient Satisfaction" }\end{array}$ & $\begin{array}{c}\text { Education } \\
\text { level }\end{array}$ & No & Mean & $\begin{array}{c}\text { Indep. var. } \\
\text { Education level }\end{array}$ & DF & $\mathbf{F}$ & p-value \\
\hline \multirow{4}{*}{ Access to Care } & Elementary & 90 & 30.3667 & \multirow{4}{*}{$\begin{array}{c}\text { Between } \\
\text { Groups }\end{array}$} & \multirow{4}{*}{$\begin{array}{c}3 \\
401\end{array}$} & \multirow{4}{*}{2.363} & \multirow{4}{*}{.071} \\
\hline & Preparatory & 105 & 31.1714 & & & & \\
\hline & Secondary & 130 & 30.0231 & & & & \\
\hline & University and more & 80 & 29.5250 & & & & \\
\hline \multirow{4}{*}{ Physical environment } & Elementary & 90 & 34.5444 & \multirow{4}{*}{$\begin{array}{l}\text { Between } \\
\text { Groups }\end{array}$} & \multirow{4}{*}{$\begin{array}{c}3 \\
401\end{array}$} & \multirow{4}{*}{4.632} & \multirow{4}{*}{$.003^{*}$} \\
\hline & Preparatory & 105 & 34.2952 & & & & \\
\hline & Secondary & 130 & 33.7385 & & & & \\
\hline & University and more & 80 & 31.9125 & & & & \\
\hline \multirow{4}{*}{ Patients' expectations } & Elementary & 90 & 44.4333 & \multirow{4}{*}{$\begin{array}{c}\text { Between } \\
\text { Groups }\end{array}$} & \multirow{4}{*}{$\begin{array}{c}3 \\
401\end{array}$} & \multirow{4}{*}{2.662} & \multirow{4}{*}{$.048^{*}$} \\
\hline & Preparatory & 105 & 45.3810 & & & & \\
\hline & Secondary & 130 & 44.4923 & & & & \\
\hline & University and more & 80 & 42.3000 & & & & \\
\hline \multirow{4}{*}{ Waiting Time } & Elementary & 90 & 38.6889 & \multirow{4}{*}{$\begin{array}{c}\text { Between } \\
\text { Groups }\end{array}$} & \multirow{4}{*}{$\begin{array}{c}3 \\
401\end{array}$} & \multirow{4}{*}{2.307} & \multirow{4}{*}{.076} \\
\hline & Preparatory & 105 & 38.9524 & & & & \\
\hline & Secondary & 130 & 37.5154 & & & & \\
\hline & University and more & 80 & 36.9000 & & & & \\
\hline \multirow{4}{*}{$\begin{array}{l}\text { Information } \\
\text { \& Interaction }\end{array}$} & Elementary & 90 & 43.7889 & \multirow{4}{*}{$\begin{array}{l}\text { Between } \\
\text { Groups }\end{array}$} & \multirow{4}{*}{$\begin{array}{c}3 \\
401\end{array}$} & \multirow{4}{*}{1.949} & \multirow{4}{*}{.121} \\
\hline & Preparatory & 105 & 42.2190 & & & & \\
\hline & Secondary & 130 & 41.2462 & & & & \\
\hline & University and more & 80 & 41.2375 & & & & \\
\hline \multirow{4}{*}{$\begin{array}{c}\text { Overall } \\
\text { satisfaction }\end{array}$} & Elementary & 90 & 191.8222 & \multirow{4}{*}{$\begin{array}{c}\text { Between } \\
\text { Groups }\end{array}$} & \multirow{4}{*}{$\begin{array}{c}3 \\
401\end{array}$} & \multirow{4}{*}{3.561} & \multirow{4}{*}{$.014^{*}$} \\
\hline & Preparatory & 105 & 192.0190 & & & & \\
\hline & Secondary & 130 & 187.0154 & & & & \\
\hline & University and more & 80 & 181.8750 & & & & \\
\hline
\end{tabular}

* P-value statistically significant at level equal or less than 0.05

Table 5. Differences in patient's satisfaction type of the visited clinic

\begin{tabular}{|c|c|c|c|c|c|c|c|}
\hline $\begin{array}{c}\text { Dep. var. } \\
\text { "Patient Satisfaction" }\end{array}$ & Visited clinic & No & Mean & $\begin{array}{l}\text { Indep.var. } \\
\text { Visited clinic }\end{array}$ & DF & $\mathbf{F}$ & p-value \\
\hline \multirow{3}{*}{ Access to care } & Surg. clinics & 129 & 30.0698 & \multirow{3}{*}{$\begin{array}{c}\text { Between } \\
\text { Groups }\end{array}$} & \multirow{3}{*}{$\begin{array}{c}2 \\
402\end{array}$} & \multirow{3}{*}{.526} & \multirow{3}{*}{.591} \\
\hline & Med. clinics & 241 & 30.4813 & & & & \\
\hline & Others & 35 & 29.8857 & & & & \\
\hline \multirow{3}{*}{$\begin{array}{c}\text { Physical } \\
\text { Environment }\end{array}$} & Surg. clinics & 129 & 33.4496 & \multirow{3}{*}{$\begin{array}{c}\text { Between } \\
\text { Groups }\end{array}$} & \multirow{3}{*}{$\begin{array}{c}2 \\
402\end{array}$} & \multirow{3}{*}{.272} & \multirow{3}{*}{.762} \\
\hline & Med. clinics & 241 & 33.8548 & & & & \\
\hline & Others & 35 & 33.5714 & & & & \\
\hline \multirow{3}{*}{ Patients' expectations } & Surg. clinics & 129 & 43.7132 & \multirow{3}{*}{$\begin{array}{l}\text { Between } \\
\text { Groups }\end{array}$} & \multirow{3}{*}{$\begin{array}{c}2 \\
402\end{array}$} & \multirow{3}{*}{1.108} & \multirow{3}{*}{.331} \\
\hline & Med. clinics & 241 & 44.7261 & & & & \\
\hline & Others & 35 & 43.2571 & & & & \\
\hline \multirow{3}{*}{ Waiting time } & Surg. clinics & 129 & 37.3256 & \multirow{3}{*}{$\begin{array}{c}\text { Between } \\
\text { Groups }\end{array}$} & \multirow{3}{*}{$\begin{array}{c}2 \\
402\end{array}$} & \multirow{3}{*}{1.551} & \multirow{3}{*}{.213} \\
\hline & Med. clinics & 241 & 38.4730 & & & & \\
\hline & Others & 35 & 37.5429 & & & & \\
\hline \multirow{3}{*}{$\begin{array}{l}\text { Information } \\
\text { \& Interaction }\end{array}$} & Surg. clinics & 129 & 41.7597 & \multirow{3}{*}{$\begin{array}{c}\text { Between } \\
\text { Groups }\end{array}$} & \multirow{3}{*}{$\begin{array}{c}2 \\
402\end{array}$} & \multirow{3}{*}{.469} & \multirow{3}{*}{.626} \\
\hline & Med. clinics & 241 & 42.0415 & & & & \\
\hline & Others & 35 & 43.3143 & & & & \\
\hline \multirow{3}{*}{$\begin{array}{c}\text { Overall } \\
\text { Satisfaction }\end{array}$} & Surg. clinics & 129 & 186.3178 & \multirow{3}{*}{$\begin{array}{c}\text { Between } \\
\text { Groups }\end{array}$} & \multirow{3}{*}{$\begin{array}{c}2 \\
402\end{array}$} & \multirow{3}{*}{.789} & \multirow{3}{*}{.455} \\
\hline & Med. clinics & 241 & 189.5768 & & & & \\
\hline & Others & 35 & 187.5714 & & & & \\
\hline
\end{tabular}

* P-value statistically significant at level equal or less than 0.05 .

\section{Differences in patient's satisfaction by level of education}

One Way ANOVA statistical test was used to determine the differences in patients' satisfaction with regard to educational level. The results exhibited that the differences were reached statistical significant in physical environment, overall satisfaction and patients' expectation (P-value $0.003,0.014$ and 0.048 respectively). The results 
revealed that the patients who were attained to elementary and preparatory education have had higher scores of satisfactions. As illustrated in the Table 4.

\section{Differences in patient's satisfaction by the time consumed in the visit}

One Way ANOVA statistical test was used to determine the differences in patients' satisfaction with regard to type of disease. The results showed that the differences were reached the statistically significant in all domains and overall satisfaction. The results revealed that the patients who spent suitable time have highest satisfaction scores and they were more satisfied, while patients who spent long time have lowest satisfaction scores and they were less satisfied, as reported in the Table 5.

\section{Discussion}

To our knowledge, this is the first study examined patient satisfaction in outpatient clinic in the governmental hospital in Gaza. It is also the first such study conducted in an Arab-speaking country.

Differences in patient's satisfaction and characteristics of the study population

This result was approved by Baker [13] who examined the characteristics of practices, general practitioners and patients related to levels of patients' satisfaction with consultations, the results indicated that women having higher satisfaction scores than men. Other study conducted Abdelrhman and Saeed (2000) who assessed patients' satisfaction with primary health care centers services in Kuwait City, the results indicated that females are usually more satisfied than males. Furthermore, this result consistent with El-Haj. M [14] who found that females were more satisfied in information and communication domain and their mean scores were higher than the males mean scores in general subscales dimensions. El-Haj. M [14] attributed this finding to that females may not know their health rights and to low expectation level. Further, another study conducted by Uzun [15] who measured patient satisfaction with nursing care in Ataturk University Hospital at Erzurm City in Turkey. The finding revealed that there was statistically significant relationship between satisfaction level and gender and gave higher scores than males. Weisman, Henderson [16] who assessed gender and patient satisfaction in managed care plans in the united states, the findings determined that there was a small but significant means differences by gender. While, other studies pointed that there were no significant differences between males and females regarding satisfaction level with radiology services in GS [17].

\section{Differences in patient's satisfaction by age groups}

This result is consistent with the study conducted by Abu-Saileek [18] who found statistical significant differences between age groups regarding the satisfaction level, also older age reported higher level of satisfaction. This result is an accordance with Uzun [15] study who found that patients between the ages of 18 to 34 gave the lowest rating of satisfaction level and patients aged between 50 to 64 years and more than 65 gave the highest rating. The researcher attributed the inconsistent relationship between satisfaction and age to the fact that patients' satisfaction is influenced by other variables rather than age of the patients.

Differences in patient's satisfaction by marital status

This result consistent with previous studies which revealed that married patients were more satisfied than unmarried patients $[14,18,19]$, while the result was inconsistent with Hillis [20] study that conducted in ASH to assess the satisfaction level among patients who need physiotherapy treatment that revealed there is no significant statistical differences in marital status.

Differences in patient's satisfaction by level of education

This result was consistent with Hillis [20] study who found that the illiteracy and primary educated patients were satisfied more than the patients with university and more. El-Haj. M [14] study was conducted in EGH in GS to assess the patients' perception level regarding the health services provided at EGH. The result illustrated that there were statistical analysis identified that the illiterate and preparatory patients reported higher scores of perception. Shaqura [21] study that conducted in Jablia women's Health Center indicated that the illiteracy clients reported higher scores of perceptions, while the university level of education reported the lowest scores of perceptions. Another study conducted by Abu-Saileek [18] to evaluate patients' level of satisfaction with nursing care in selected hospitals in south of GS found that there are significant differences within educational level regarding satisfaction level, the client' who had lower educational level were more satisfied with nursing care than the clients' who had higher educational level. The result was consistent also with Aday and Walker Jr [22] study showed that the patients with lower level of education showed higher of satisfaction with availability of services and facilities, and those with higher of education tended to be more satisfied with the quality of care. Shaqura [21] study revealed that the least satisfied group is the highly educated one. On the other hand, Al Hindi [17] study conducted in GS to evaluate satisfaction level with radiology services indicated that higher level of education reported higher satisfaction level and concluded that because those with higher educational level might be more informed about the services.

This result was consistent with the result of [14,15] studies that found the patients who admitted to the medical wards elicited higher level of the overall perception scores, while the patients who admitted to the surgical wards reported lower level. This result is in contrast with a study conducted by Abu-Saileek [18] who revealed that the client's from surgical wards and medical wards were in the same level of satisfaction. This result may have attributed to the frequently of patients visiting the medical clinics rather than the surgical ones, this makes the patients who have medical diseases to be more cooperative and understanding the treatment process than surgical patients.

\section{Differences in patient's satisfaction by the time} consumed in the visit

This result is consistent with the study conducted by $\mathrm{Al}$ Hindi [17] who indicated that the clients who waited the shortest time tend to be more satisfied than the others who waited long time. Furthermore, Bialor, Gimotty [23] found that the patients who waited shorter waiting time 
reported a higher satisfaction score than the patients who waited longer waiting time. Hillis [20] (2008) in her study that conducted in ASH and AL-Wafa hospital to assess patient's satisfaction with physiotherapy found that there were no significant statistical differences between waiting time and patients' satisfaction. Other study, found that the mixed results of the relationship between waiting time and patient satisfaction is unclear manner [24]. Several researchers like urged that long waiting time is major item of patients' dissatisfaction [25]. This result could be attributed to the huge number of patients who attend daily to the clinic, overload in the OPsDfor three or four hours and to the appointment system that present in the OPsD.

\section{Conclusion}

The health care production has become extremely competitive since the recent past. Only those organizations that have information about their clients have strategies to meet their expectations. Therefore, there has been an extraordinary demand for feedback from patients and their employers about their health care plans or their individual providers or health care organizations. Ratings of different dimensions of satisfaction have been greatly correlated in some studies, and scores on these dimensions have been added to give up overall satisfaction ratings. However, responses to particular items are of interest to service providers who want to find out how a particular aspect of the service could be improved.

\section{References}

[1] Sitzia J, Wood N. Patient satisfaction: a review of issues and concepts. Social science \& medicine. 1997; 45(12): 1829-43.

[2] Al Sharif BFT. Patient's Satisfaction With Hospital Services At Nablus District, West Bank, Palestine: An-Najah National University; 2008.

[3] Kerr EA, Hays RD, Mitchinson A, Lee M, Siu AL. The influence of gatekeeping and utilization review on patient satisfaction. Journal of general internal medicine. 1999; 14(5): 287-96.

[4] Kovai V, Rao GN, Holden B. Key factors determining success of primary eye care through vision centres in rural India: Patients' perspectives. Indian journal of ophthalmology. 2012; 60(5): 487.

[5] Yousef A, Naeem A. Patients' Satisfaction with the Quality of Health Services Provided at the Outpatient Department at Al-Shifa Hospital. 2010.

[6] Ziaei H, Katibeh M, Eskandari A, Mirzadeh M, Rabbanikhah Z, Javadi MA. Determinants of patient satisfaction with ophthalmic services. BMC research notes. 2011: 4(1): 7.
[7] Ibrahim A, Chompikul J, Isaranurug S. Patient satisfaction with health services at the outpatient department of Indira Gandhi memorial Hospital, Male'Maldives. Journal of public health and development. 2008; 6(1): 144-52.

[8] Sudhan A, Khandekar R, Deveragonda S, Devi S, Jain B, Sachan $\mathrm{R}$, et al. Patient satisfaction regarding eye care services at tertiary hospital of central India. Oman journal of ophthalmology. 2011; 4(2): 73.

[9] Mourad TA, Shashaa S, Markaki A, Alegakis A, Lionis C, Philalithis A. An evaluation of patients' opinions of primary care physicians: the use of EUROPEP in Gaza Strip-Palestine. Journal of medical systems. 2013; 31(6): 497-503.

[10] Schoenfelder T, Klewer J, Kugler J. Determinants of patient satisfaction: a study among 39 hospitals in an in-patient setting in Germany. International journal for quality in health care. 2011; 23(5): 503-9.

[11] Dawson B, Trapp RG, Trapp RG. Basic \& clinical biostatistics: Lange Medical Books/McGraw-Hill New York; 2004.

[12] Cohen J. A power primer. Psychol Bull. 1992; 1(112): 155.

[13] Baker R. Characteristics of practices, general practitioners and patients related to levels of patients' satisfaction with consultations. Br J Gen Pract. 1996; 46(411): 601-5.

[14] El-Haj. M. Perceptions of Hospitalized Patients about the Services Provided at the European Gaza Hospital. : Al-Quds University, Palestine.; 2008.

[15] Uzun Ö. Patient satisfaction with nursing care at a university hospital in Turkey. Journal of Nursing Care Quality. 2001; 16(1): 24-33.

[16] Weisman CS, Henderson JT, Schifrin E, Romans M, Clancy CM. Gender and patient satisfaction in managed care plans: analysis of the 1999 HEDIS/CAHPS $2.0 \mathrm{H}$ Adult Survey. Women's Health Issues. 2001; 11(5): 401-15.

[17] Al Hindi F. Clients' Satisfaction with Radiology Services in Gaza. Master of Public Health Thesis, Al-Quds University, Palestine. 2002.

[18] Abu-Saileek M. Clients' Satisfaction with Nursing Care Provided at Selected Hospitals in Gaza Strip. Master of Nursing Management Thesis Al-Quds University, Palestine. 2004.

[19] Al-Doghaither AH. Inpatient satisfaction with physician services at King Khalid University Hospital, Riyadh, Saudi Arabia. East Mediterr Health J. 2004; 10(3): 358-64.

[20] Hillis JM. Dean of Graduate Studies Faculty of Education Psychology Department: Islamic University-Gaza.

[21] Shaqura M. Evaluation of the Quality of Reproductive Health Services in Jabalia Women's Health Center: Client's Perspective. Master of Public Health Thesis Al-Quds University, Palestine. 2008.

[22] Aday LA, Walker Jr GM. Patient satisfaction in government health facilities in the state of Qatar. Journal of community health. 1996; 21(5): 349-58.

[23] Bialor BD, Gimotty PA, M P, J F. The effect of primary care training on patient satisfaction ratings. Journal of general internal medicine. 1997; 12(12): 776-80.

[24] Gadallah M, Zaki B, Rady M, Anwer W, Sallam I. Patient satisfaction with primary health care services in two districts in Lower and Upper Egypt. 2003.

[25] Ali MES, Mahmoud MEA. A study of patient satisfaction with primary health care services in Saudi Arabia. Journal of community health. 1993; 18(1): 49-54. 